\title{
COMPARATIVE STUDY BETWEEN INCIDENCE OF HELICOBACTER PYLORI INFECTION IN WOMEN WITH HYPEREMESIS GRAVIDARUM AND NORMAL PREGNANCY
}

\author{
By
Fahd Abd El-Aal Al-Omda ${ }^{1}$, Ashraf Hamdy Mohamed, Mahmoud Abd El-Latif Hashish* and Mohamed Abd Allah Bedier Abd Allah \\ Departments of Obstetrics \& Gynecology and Clinical Pathology*, Faculty of Medicine, \\ Al- Azhar University \\ E-mail: abdallahmohmed892@gmail.com
}

\begin{abstract}
Background: Nausea and vomiting in early pregnancy is so common that it can be considered a normal part of pregnancy. It is referred to as "morning sickness" although this is a misnomer because symptoms will often persist throught the day. Nausea and vomiting occurs significantly more often in primigravidas and women who were less educated younger-nonsmokers, obese or those with a history of nausea and vomiting in previous pregnancy.

Objective: This work aimed at assessing the possible relation between $\mathrm{H}$. Pylori infection and hyperemesis gravidarum (HG).

Patient and Methods: Study setting: Al Azhar University Hospitals (Al_ Hussein and Sayed Galal), Duration of study: November 2018 to May 2019. The Study included two groups Group (A): (Thirty) pregnant women with hyperemesis gravidarum in the first trimester attending at antenatal clinics and admitted in the ward in addition to Group (B): (Thirty) normal pregnant women with antenatal care. The pregnant women with hyperemesis gravidarum, aged 18-40 years old and less than 16 weeks gestation.

Results: The current study found significant difference between two groups regarding positivity of HPSA. Positive stool antigen were found in 26 out of 30 of hyperemesis gravidarum (86.7\%) compared with 11 out of 30 controls (36.7\%) and highly statistical significant difference between studied groups as regard $\mathrm{H}$ pylori antibodies.
\end{abstract}

Conclusion: There was a significant association between Helicobacter Pylori infection and pathogenesis of hyperemesis gravidarum.

Keywords: Hyperemesis gravidarum.

\section{INTRODUCTION}

Nausea and vomiting in early pregnancy is so common that it can be considered a normal part of pregnancy. It is referred to as "morning sickness" although this is a misnomer because symptoms will often persist through the day. Symptoms usually begin between the fourth and seventh week after the last menstrual period and resolve in many women by the twelfth week and in most women by twentieth week of pregnancy (Niebyl, 2010).

The condition is usually self-limiting and peaks at around 9th gestational week. However, in up to $20 \%$ of cases nausea 
and vomiting may continue until delivery. Nausea and vomiting occurs significantly more often in primigravidas and women who were less educated youngernonsmokers, obese or those with a history of nausea and vomiting in previous pregnancy (Jueckstock et al., 2010).

Symptoms including nausea, gagging, retching and vomiting may persist 'round the clock despite the common term morning sickness (Clark et al., 2014).

A smaller number of pregnant women (approximately $0.3-1 \%$ ) have a more severe form of nausea and vomiting hyperemesis gravidarum which is characterised by persistent vomiting, weight loss of more than $5 \%$, ketouria, electrolyte abnormalities (hypo-kalaemia) and dehydration (O'Carroll et al., 2011).

H.pylori has been recognized to play a role in disease of gastrointestestial tract. It has been hypothesized that H.pylori may increase the risk of hyperemesis gravidrum (Irene Sanddven et al., 2009).

Helicobacter pylori is a spiral-shaped, gram-negative bacterium that is found in the gastric mucous layer or is adherent to the epithelial lining of the stomach. Most people who are infected by $H$. pylori never suffer any symptoms related to the infection; however, $\mathrm{H}$ pylori is associated with chronic gastritis, gastroduodenal ulcers, duodenal structural and functional abnormalities, and gastric malignancies (Guven et al., 2011).

Hyperemesis gravidarum is an intractable nausea and vomiting sign of delay duration such as ketonuria, high urine specific gravity, electrolyte imbalances, and weight loss of at least $5 \%$ of pre-pregnancy weight ketosis and need for admission to hospital (Mella, 2011).

This work aimed to assess the possible relation between $\mathrm{H}$. Pylori infection and hyperemesis gravidarum.

\section{PATIENTS AND METHODS}

Study setting: Al_Azhar university hospitals (Al_ Hussein and Sayed Galal).

Duration of study: November2018 to May2019.

Study design: Case control study.

\section{This work contained 2groups:}

1. Group (A): (30patiant) pregnant women with hyperemesis gravidarum who have vomiting sufficiently enough to produce weight loss, dehydration and hypokalemia and admitted in hospital.

2. Group (B): (30patiant) Control patients which have been selected from pregnant women presenting to the outpatient clinics for routine antenatal care at the same gestational age. Some age range and some socioeconomic standard as cases.

All controls have no gastro-intestinal symptoms and had the same exclusion criteria of the cases.

\section{All women were subjected to:}

1. Full history taking.

2. Clinical examination (general and abdominal).

3. Investigations.

- Complete blood count.

- Complete urine analysis.

- Liver and kidney function test.

- Coagulation profile (PT, PTT and INR). 
- Electrolytes (serum $\mathrm{Na}+, \mathrm{K}+$ ).

- Abdominal ultrasound.

- The investigator was ensured that all persons assisting with the trial were adequately informed about the protocol.

- Before begin admitted to the clinical study. Written consent was taken from every woman in the study. After proper conselling and explanation of the study in a form understandable to her.

\section{a. Fetal assessment:}

Trans-abdominal ultrasound including fetal viability and gestational age.

\section{b. H. pylori infection assessment:}

One step H.pylori stool antigen test.

All pregnant women (cases and controls) were asked to bring a stool sample in a clean container; collected sample was tested in a laboratory.

Stool sample was tested by using one step H.pylori stool antigen test (CER test Biotec) Pol. Industrial Rio Gallego II Calle J. No. 1-5. No 1. 50840 for detection of H.pylro antigen.

\section{Inclusion criteria:}

- Age of patients between 18-40 years old.

- Fetal single viable fetus in ultrasound.

- Gestational age less than 16 wks confirmed by pelvic ultrasound and LMP.

\section{Exclusion criteria:}

- Multiple pregnancies.

- Hydatidiform molar pregnancy.

- Other causes of vomiting:

- Gastroentritis.

- Cholecystitis.

- Pyelonephritis.

- Liver dysfunction.

- Hyperthyroidism.

\section{Statistical analysis:}

Data were analyzed using Statistical package for Social Science (SPSS) version 15.0. Quantitative data were expressed as mean \pm standard deviation (SD). Qualitative data were expressed as frequency and percentage.

\section{The following tests were done:}

Independent-samples t-test of significance: was used when comparing between two means.

Chi-square test: was used when comparing between qualitative data.

- P-value < 0.05 was considered significant.

- Mann-Whitney-U test was used to compare mean scores of continued variables between two groups in abnormally distributed samples. $\mathrm{P}$ value of less than 0.05 was considered as statistically significant. 


\section{RESULTS}

Thirty pregnant women with hyperemesis gravidarum and gestational age-matched 30 control subject were enrolled in the study.

There were no statistically significant differences between the study groups with hyperemesis gravidarum and control groups in terms of age, gestational week, parity, educational level and socioeconomic state (Table 1).

Table (1): Comparison between studied groups as regard demographic data

\begin{tabular}{|c|c|c|c|c|}
\hline \multicolumn{2}{|c|}{$\begin{array}{ll}\text { Variables } & \text { Groups } \\
\end{array}$} & $\begin{array}{c}\text { Group A } \\
(\mathbf{N}=\mathbf{3 0})\end{array}$ & $\begin{array}{c}\text { Group B } \\
(\mathbf{N}=\mathbf{3 0})\end{array}$ & P-value \\
\hline \multirow{2}{*}{ Age (years) } & Mean & 28.5 & 31.7 & \multirow{2}{*}{0.122} \\
\hline & \pm SD & 8.4 & 7.4 & \\
\hline \multirow{2}{*}{$\begin{array}{l}\text { Gestational } \\
\text { Age (weeks) }\end{array}$} & Mean & 9.5 & 8.9 & \multirow{2}{*}{0.191} \\
\hline & \pm SD & 1.6 & 1.9 & \\
\hline \multirow{3}{*}{ Parity } & Para 0 & $18(60 \%)$ & $17(56.7 \%)$ & 0.793 \\
\hline & Para 1 & $6(20 \%)$ & $8(26.7 \%)$ & 0.541 \\
\hline & Para 2 & $6(20 \%)$ & $5(16.7 \%)$ & 0.738 \\
\hline \multirow{2}{*}{$\begin{array}{l}\text { Socioeconomic } \\
\text { state }\end{array}$} & Low & $24(80 \%)$ & $22(73.3 \%)$ & \multirow{2}{*}{0.541} \\
\hline & Intermed. & $6(20 \%)$ & $8(26.7 \%)$ & \\
\hline \multirow{2}{*}{$\begin{array}{c}\text { Educational } \\
\text { level }\end{array}$} & Not educated & $20(66.7 \%)$ & $22(73.3 \%)$ & \multirow{2}{*}{0.573} \\
\hline & Primary school & $10(33.3 \%)$ & $8(26.7 \%)$ & \\
\hline
\end{tabular}

They were statistically significant differences between studied groups as regard kidney function tests (urea and Creat) and liver enzymes (SGPT and
SGOT), and $\mathrm{Na}$, K, coagulation profile, acetone. No statistical significant differences between studied groups as regard $\mathrm{Hb}$, WBCS and PLT (Table 2). 
Table (2): Comparison between studied groups as regard kidney function tests, liver enzymes , $\mathrm{Na}, \mathrm{K}$, coagulation profile, acetone and blood picture

\begin{tabular}{|c|c|c|c|c|}
\hline \multicolumn{2}{|c|}{$\begin{array}{ll}\text { Variables } & \text { Groups } \\
\end{array}$} & $\begin{array}{c}\text { Group A } \\
(\mathbf{N}=\mathbf{3 0})\end{array}$ & $\begin{array}{c}\text { Group B } \\
(\mathbf{N}=\mathbf{3 0})\end{array}$ & P-value \\
\hline \multirow{2}{*}{ Urea (mg/dl) } & Mean & 21.1 & 24.56 & \multirow{2}{*}{0.005} \\
\hline & \pm SD & 8.3 & 5.30 & \\
\hline \multirow{2}{*}{ Creat (mg/dl) } & Mean & 0.71 & 0.79 & \multirow{2}{*}{0.022} \\
\hline & \pm SD & 0.23 & 0.16 & \\
\hline \multirow{2}{*}{ SGPT (U/L) } & Mean & 56.03 & 35.32 & \multirow{2}{*}{$<0.001$} \\
\hline & \pm SD & 22.34 & 7.20 & \\
\hline \multirow{2}{*}{ SGOP (U/L) } & Mean & 43.97 & 26.64 & \multirow{2}{*}{$<0.001$} \\
\hline & \pm SD & 18.73 & 4.82 & \\
\hline \multirow{2}{*}{$\mathrm{Na}(\mathbf{m E q} / \mathbf{L})$} & Mean & 132.86 & 142.17 & \multirow{2}{*}{$<0.001$} \\
\hline & \pm SD & 4.2 & 5.01 & \\
\hline \multirow{2}{*}{$\mathbf{K}(\mathbf{m E q} / \mathbf{L})$} & Mean & 3.3 & 4.00 & \multirow{2}{*}{$<0.001$} \\
\hline & \pm SD & 0.6 & 0.69 & \\
\hline \multirow{2}{*}{$\begin{array}{c}\text { Prothrombin } \\
\text { concentration }(\%)\end{array}$} & Mean & 90.19 & 82.18 & \multirow{2}{*}{$<0.001$} \\
\hline & \pm SD & 9.57 & 6.93 & \\
\hline \multirow{2}{*}{ INR } & Mean & 1.23 & 1.44 & \multirow{2}{*}{$<0.01$} \\
\hline & \pm SD & 0.27 & 0.37 & \\
\hline \multirow{2}{*}{ APTT (Sec) } & Mean & 34.97 & 32.40 & \multirow{2}{*}{$<0.03$} \\
\hline & \pm SD & 3.49 & 5.31 & \\
\hline \multirow{2}{*}{ Acetone } & Negative & $0(0 \%)$ & $9(30 \%)$ & \multirow{2}{*}{$<0.001$} \\
\hline & Positive & $30(100 \%)$ & $21(70 \%)$ & \\
\hline \multirow{2}{*}{$\mathrm{Hb}(\mathrm{g} / \mathrm{dl})$} & Mean & 9.2 & 11.60 & \multirow{2}{*}{$>0.188$} \\
\hline & \pm SD & 1.3 & 1.98 & \\
\hline \multirow{2}{*}{ WBCs $\left(\times 10^{3} / \mathrm{ul}\right)$} & Mean & 10.2 & 7.57 & \multirow{2}{*}{$>0.135$} \\
\hline & \pm SD & 7.6 & 2.34 & \\
\hline \multirow{2}{*}{ PLT (x10³/ul) } & Mean & 244.97 & 251.94 & \multirow{2}{*}{$>0.399$} \\
\hline & \pm SD & 87.37 & 80.82 & \\
\hline
\end{tabular}

They were shows statistically significant difference between studied groups as regard $\mathrm{H}$ pylori $\mathrm{Ag}$ in stool and $\mathrm{H}$ pylori antibodies (Table 3 ).

Table (3): Comparison between studied groups as regard $\mathbf{H}$ pylori $\mathrm{Ag}$ in stool and $\mathbf{H}$ pylori antibodies

\begin{tabular}{|c|c|c|c|c|}
\hline \multicolumn{2}{|c|}{$\begin{array}{ll}\text { Variables } & \text { Groups } \\
\end{array}$} & $\begin{array}{c}\text { Group A } \\
(\mathbf{N}=\mathbf{3 0})\end{array}$ & $\begin{array}{c}\text { Group B } \\
(\mathbf{N}=\mathbf{3 0}) \\
\end{array}$ & P-value \\
\hline \multirow{2}{*}{$\begin{array}{c}\text { H pylori Ag in } \\
\text { stool }\end{array}$} & Negative & $4(13.3 \%)$ & $19(63.3 \%)$ & \multirow{2}{*}{$<0.001$} \\
\hline & Positive & $26(86.7 \%)$ & $11(36.7 \%)$ & \\
\hline \multirow{2}{*}{ H pylori Abs } & Mean & 58.97 & 31.23 & \multirow{2}{*}{$<0.001$} \\
\hline & \pm SD & 25.91 & 28.66 & \\
\hline
\end{tabular}




\section{DISCUSSION}

The study included $30 \mathrm{pt}$ with HG patients were confirmed with $\mathrm{H}$ pylori infection implied that the rate of Hpylori infection was much greater in $\mathrm{HG}$ patients than that in non $\mathrm{HG}$ patients after adjusting for cofounding variables

There was no significant difference between the two groups regarding demographic data (age, gestational age and socioeconomic status).

There was statistically significant difference between studied groups as regard kidney function tests (urea and Creat) as they found decrease in urea in group A than group B. Mean creat decrease in group A than group B. and this study was agreed with study carried out by Rasha (2015).

And there was statistical significant difference between studied groups as regard liver enzymes (SGPT and SGOT). They found increase in group A than group B. Mean SGOP increase in group A than in group B and this study was agreed with study carried out by Rasha (2015).

And there was statistical significant difference between studied groups as regard $\mathrm{Na}$ and $\mathrm{K}$ they found decrease in group A than group B. Mean $\mathrm{K}$ they found decrease in group A than group B.

No statistical significant difference between studied groups as regard $\mathrm{Hb}$, WBCs \& PLT.

The current study found significant difference between two groups regarding positivity of HPSA. Positive stool antigen were found in 26 out of 30 of hyperemesis gravid arum $(86.7 \%)$ compared with 11 out of 30 controls (36.7\%) This study found that the rate of $\mathrm{H}$. pylori infection was higher in $\mathrm{HG}$ patients than that in non-HG patients and this was agreed with study carried out by Guven and colleagues which investigated the relationship between $\mathrm{H}$. pylori infection and $\mathrm{HG}$ in early pregnancy through serologic and stool antigen tests in a prospective crosssectional study on 40 women with $\mathrm{HG}$ and 40 controls at 7-12 weeks of pregnancy. They found that the rate of serologyspecific $\mathrm{H}$. pylori $\mathrm{IgG}$ positivity was $80 \%$ in subjects with $\mathrm{HG}$ and $35 \%$ in controls-a significant difference. There was also a significant difference in the rate of $\mathrm{H}$. pylori stool antigen test positivity, with a rate of $87.5 \%$ in subjects with $\mathrm{HG}$ and $62.5 \%$ in controls (Guven et al., 2011).

In the other study a serum antiHelicobacter pylori IgG antibody by ELISA> 1.1 was associated with hyperemesis gravidarum at a sensitivity of $86.67 \%$, a specificity of $65.91 \%$, a positive predictive value of $72.22 \%$, a negative predictive value of 82.86 (Mansour and Nashaat, 2011).

Also, Abdl Alwahed et al. found that Hyperemesis gravid arum patients were found to have a significantly higher Helicobacter Pylori prevalence compared to control subjects (69\% vs. $15 \%$; p $<0.05)$ especially in intractable cases where the Helicobacter Pylori prevalence is $80 \%$. The hyperemesis gravid arum patients were found to have a significantly higher HpSA positivity compared to control group ( $\mathrm{p}<0.05$ ) (Abdl Alwahed et al., 2014).

Study also carried out by Ahmed et al. Shows significantly high prevalence of $\mathrm{H}$. pylori among pregnant with hyperemesis gravid arum compared to control group 
$(80 \%$ vs. $15 \%$,). Patients with hyperemesis gravid arum were found to have significantly higher in HPSA positive compared to control group (Ahmed et al. 2014).

Also, AlBasam \& Obaid reported that the rates of $\mathrm{H}$ pylori stool antigen test positivity were $52 \%$ (26 out of 50) among patients with $\mathrm{HG}$ and $18 \%$ (9 out of 50) in control group. The difference between the two groups was statistically significant. $\mathrm{P}$ value < 0.05 (AlBasam \& Obaid, 2013).

Cases and controls in this study were recruited from the clinics of Al_Hussein and Sayed Galal Hospital where medical service is almost free. This explains the same socioeconomic level of all women participated in this study.

In this study, it was mentioned that all the study participants were from areas of low socioeconomic status; this situation was designated only by the education level. The prevalence of $\mathrm{H}$ pylori in our region was 86.7 by stool antigen test, which indicates active infection in $\mathrm{HG}$ cases, and this rate is higher than those in other control studies 36.7.

Patients' education for food safety was important. Careful food handling and hand washing were important to prevent transmission of foodborne pathogens to the diet of pregnant women. Patients' education for food safety should be considered to prevent the increasing numbers of infected cases especially in developing countries with low socioeconomic levels.

Further case reports described that there was significant improvement in patients with hyperemesis gravid arum and a positive Helicobacter pylori serum titer after treatment with clarithromycin and/or amoxicillin and a proton pump inhibitor (lansoprazole or omeprazole) or $\mathrm{H} 2$-antagonists (famotidine or ranitidine).

The advantages of the antibody tests were their low cost, widespread availability, and rapid results.

Early detection for Helicobacter pylori and proof of eradication are the keys for preventing severe consequences of infection. And stool antigen test which detect active infection and it is noninvasive, cheap and easy test. Although serologic testing is the most common noninvasive diagnostic method for $\mathrm{Hp}$ and is relatively inexpensive and convenient, in our opinion a test that shows an active gastrointestinal colonization will be more appropriate in diagnosis of patients with $\mathrm{HG}$.

\section{LIMITATION OF THE STUDY}

1. Small sample size as statistical normally required lager sample size to ensure and preventative distribution of the population.

2. Study demonstrated the pathogenesis of $\mathrm{H}$. pylori in hyperemesis gravid arum but not treated it.

\section{CONCLUSION}

A significant association between Helicobacter Pylori infection and pathogenesis of hyperemesis gravid arum.

\section{RECOMMENDATION}

- It is recommended to add Helicobacter Pylori stool antigen test as a screening test to investigations for all women who are complaining of hyperemesis gravid arum as it is noninvasive, cheap and easy test. 
- It is highly recommended to exclude Helicobacter Pylori infection in resistant cases of hyperemesis gravid arum to routine treatment or deteriorating cases of hyperemesis gravid arum.

- Finally, when Helicobacter Pylori infection is discovered before pregnancy, it is recommended to receive treatment for Helicobacter Pylori before pregnancy

\section{REFERENCES}

1. Abdl Alwahed AR, Elsaadany HM, Radwan AM, Noureldin MA and Kumar RK (2014): Role of helicobacter eradication in the management of hyperemesis gravid arum. Research Journal of Obstetrics and Gynecology, 7(1):6-13.

2. Ahmed KT, Almashhrawi AA, Rahman RN, Hammoud GM and Ibdah JA (2013): Liver diseases in pregnancy: diseases unique to pregnancy. World Journal of Gastroenterology, 19(43): 7639 7646.

3. AlBasam AN and Obaid SA (2013): Comparison between serological assay and stool antigen for Helicobacter pylori in primigravida with Hyper-emesis gravid arum. Iraqi Journal of Gastroenterology, 7(1):102-107.

4. Bezircioğlu İ, Elveren HB, Baloğlu A Biçer M (2011): The positivity of Helicobacter pylori Stool Antigen in patients with Hyperemesis gravid arum. Journal of the Turkish German Gynecological Association, 12(2); 71-74.

5. Clark SM, Dutta $E$ and Hankins GD (2014): The outpatient management and special considerations of nausea and vomiting in pregnancy. In Seminars in perinatology; 38(8):496-502. WB Saunders.

6. Guven M A, Ertas I E, Coskun A, and Ciragil P (2011): Serologic and stool antigen assay of Helicobacter pylori infection in hyperemesis gravid arum: Which test is useful during early pregnancy? Taiwanese Journal of Obstetrics and Gynecology, 50 (1):37-41.

7. Irene $S$, Michael $A$, Britt-Ingjerd $\mathbf{N}$ and Kjetil KM (2009): Helicobacter pylori infection and hyperemesis gravid arum. Acta Obstetricia et Gynecologica, 88: 11901200.

8. Jueckstock JK, Kaestner R and Mylonas I (2010): Managing hyperemesis gravid arum: a multimodal challenge. BMC medicine; 8:46-51.

9. Mansour GM and Nashaat EH (2011): Role of Helicobacter pylori in the pathogenesis of hyperemesis gravid arum. Archives of Gynecology and Obstetrics, 284 (4):843-847.

10. Mella MT (2011): Nausea/vomiting of pregnancy and hyperemesis gravid arum. In: Berghella $\mathrm{V}$ editor(s). Maternal-fetal Evidence Based Guidelines. 2. New York City, New York USA: Informa Healthcare, 72-80.

11. Niebyl JR (2010): Nausea and vomiting in pregnancy. New England Journal of Medicine, 363(16):1544-1550.

12. O'Carroll A, O'Reilly $F$ and Whitford DL (2011): What has happened to people affected by thalidomide 50 years on? Iraq Journal of Medical Science, 180(2):475478.

13. Rasha F (2015): The Association of Helicobacter Pylori in the Pathogenesis of Hyperemesis Gravid arum in Pregnant Women, U.S. National library of medicine, clinical trials.gov: 50_54 
در اسة مقارنة بين الإصابة بالجرثومة الحلزونية في النساء

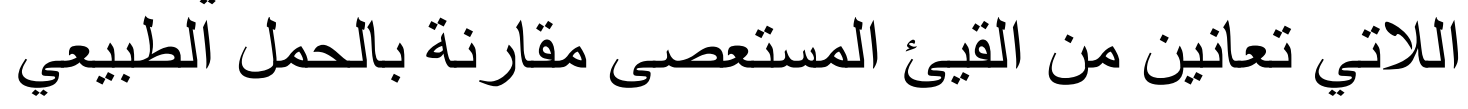
فهذ عبدالعال العمدة، أثرف حمدي محمد- محمود عبداللطيف حثيش، محمد عبدالله بدير عبدالله

قسمى النساء والتوليد والباثولوجيا الاكلينيكيه، كليه طب الازهر

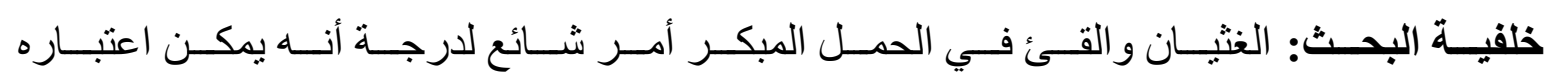

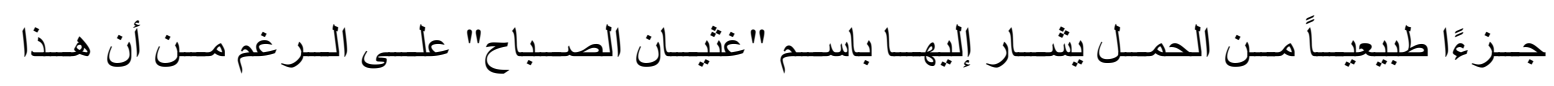

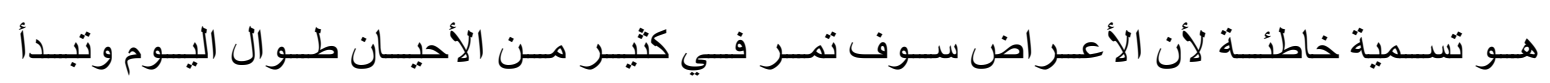

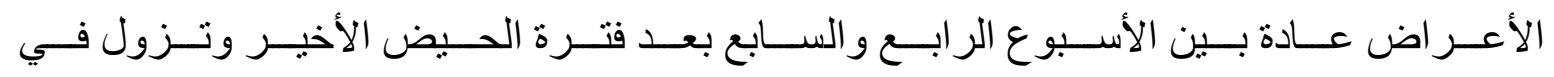

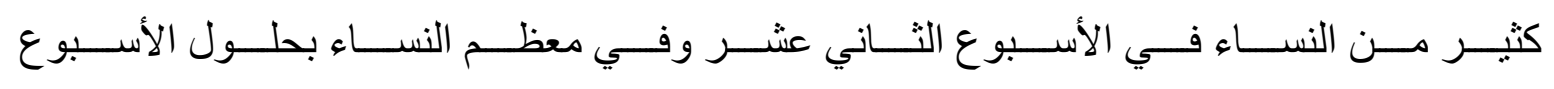

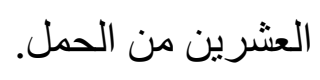

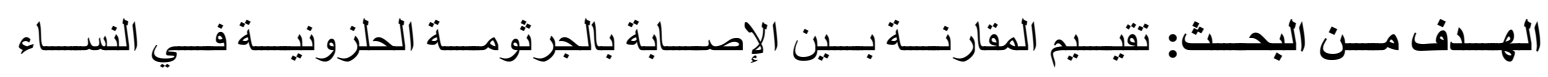
اللاتي تعانين من القئ المستعصى مقارنة بالحمل الطبيعي.

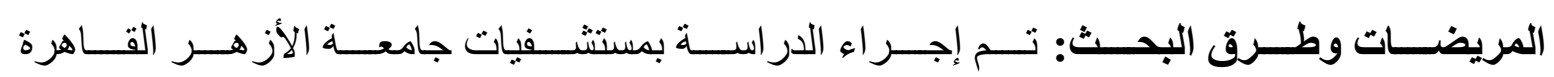

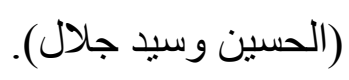

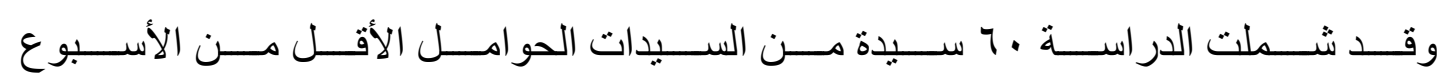
السادس عثر من الحمل حيث ثم تقسيمهين إلى مجمو عتين :

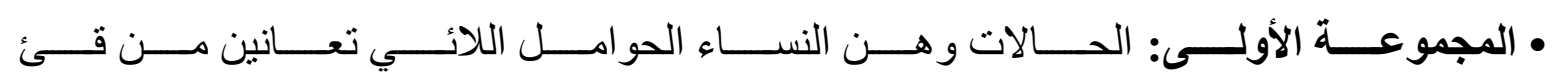
مستعصى مع الحمل وتم حجز هن بالقسم الداخل بالمستشفى.

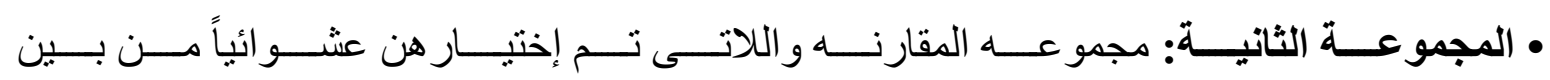

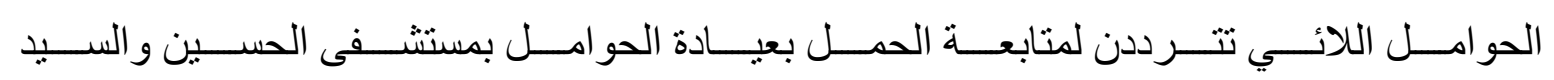

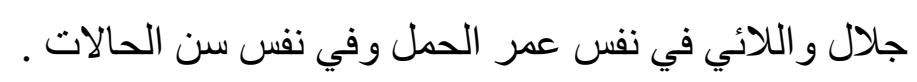

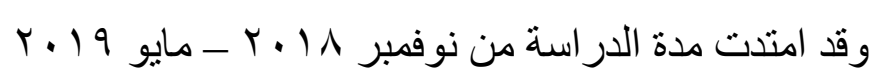




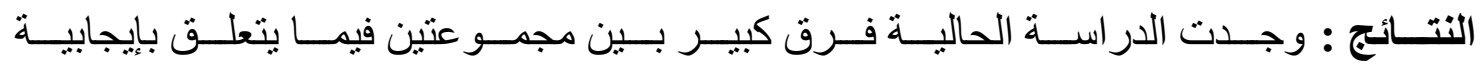
HPSA

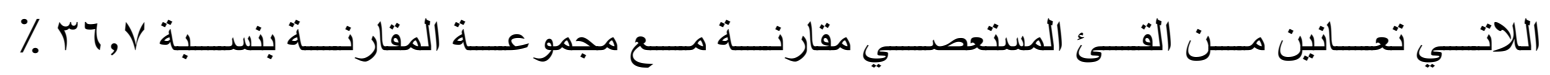

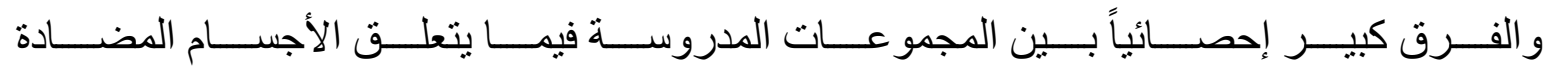

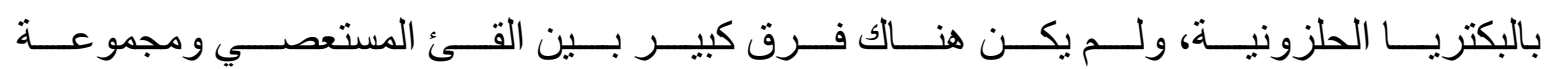

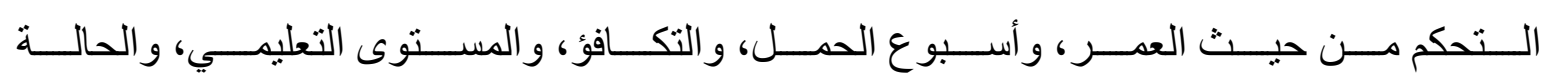
الاجتماعية و الاقتصادية و التذخين.

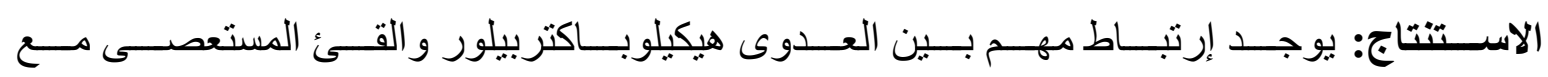
الحمل. 